\title{
Age aspect of psychological rehabilitation potential of patients with depressive disorders and its influence on the process of rehabilitation
}

\author{
I. F. Arshava, *V. V. Kornienko \\ Oles Honchar Dnipro National University \\ *Corresponding author. E-mail: viktoria_korn@ukr.net \\ Paper received 02.02.19; Accepted for publication 08.02.19.
}

\author{
https://doi.org/10.31174/SEND-PP2019-188VII77-17
}

\begin{abstract}
The increasing prevalence of depressive disorders in the world predetermines the importance of deep study of specifics of psychological component of rehabilitation potential and adaptation mechanisms of the personality with specified pathology, establishment age-old relationships with adaptive, personal, motivational, interpersonal and pathopsychological components of the psychological rehabilitation potential of patients with depressive disorders, ground, development and implementing a differentiated rehabilitation programme for integration patients with depressive disorder into society
\end{abstract}

Keywords: rehabilitation potential, adaptation, depressive disorders, mental health, rehabilitation.

Problem identification. The current state of Ukrainian society development is characterized by political, social and economic changes that are reflected in the person in the form of mental and physical strain with violations at social, biological and psychological levels. The increase in the prevalence of mental disorders is the result of modern requirements of society to the individual, which determines the urgency and deep study and improvement of existing approaches to the identification of their psychological rehabilitation potential in order to establish social and psychological positions.

It was established that psychological rehabilitation potential of patients with depressive disorders forms a symptom complex, which includes features of viability, personal adaptation potential, coping strategies, interpersonal and family communication, social functioning, specificity of value-motivational sphere, individual-typological features and psychological wellbeing of patients with depressive disorders. However, age aspect regarding the component of psychological rehabilitation potential of patients with depressive disorders has not been studied enough yet.

The analysis of recent scientific researches and publications comprise scientific developments and fundamental provisions on various aspects of psychological rehabilitation in the work of domestic and foreign scientists: L. Wasserman, M. Zotkin, A. Nalchaidyan, J. Porokhin, AA, Risher, S. Kasper and socio-psychological adaptation - I.F.Arshava, E.L. Nosenko, S.Maksimenko, T. Ayvazyan, S. Posohova, F. Berezin, Yu.Gubachov, N.Zavatska, A. Zakharov, M. Khalak. Research works of K. Ostrovsky., V. Abramov, O. Gavrilov, K. Maksymenko, N. Maksimova [1, 2, 3, 5, 10, 13, 14, 15].

The objective of the current study is to determine the age component of psychological rehabilitation potential of patients with depressive disorders.

Presenting main material. It has been proved that psychological and medical-social consequences of depression are varied and difficult. They include: high suicide risk, violation of adaptive capacity of patients, decreasing in professional status, family disintegration, disability, loss of social ties and also decreasing in the quality of life in general (Yevseyev A.A., 2012; Pschuk N.G. and Sovitsa, 2013; Borsukov A.V., Osipova M.M, 2014; Podsevatkina S.V., Podsevatkina V.G., 2014; Osipova M.M., Sinitsin S.N., 2015; Bohan T. G. et al., 2016; Saduakasova K. Z. 2017; Rhymerz., 2012; S. Kasper, 2013, Kondryukova V., 2011) [11].

It is also determined that depression is the leading cause of disability and occupies the fourth place in terms of the level of material damage inflicted on society. At the same time, a significant part of these costs is associated with temporary and permanent disability (Pilling S. et al., 2009; WHO, 2012). So, according to pharmacoeconomic studies, in the United States, the annual loss from depression is estimated at about 83 billion dollars (Greer T.L., Kurian B.T., Trivedi M.H., 2010), and in the European Union - 75 billion Euros (McIntyre R.S., Cha D.S., Soczynska J.K .et al., 2013). The biggest economic losses are due to the lack of a patient at the workplace or due to the decrease in labor productivity because of depression, despite the formal presence of an employee. As a result of depression, in average 27 working days per employee during a year is lost (Moorev M.V., Lubov Ye.B, 2011, Maruta N.O., 2015) [21].

All the above - mentioned indicates the need of studying and implementing measures for integration patients with depressive disorders into society.

The concept of rehabilitation potential originated in the immediate rehabilitation process, which determines the impact of the personality himself on the rehabilitation process.

Voytenko R.M. (2011) in terms of rehabilitation potential considers a person who suffers from disease or defect,his ability (medico-biological, social, psychological) to level out, reduce or compensate social insufficiency and (or) limitation of vital activity. Khalak (2012): "Rehabilitation potential is a complex of biological and psychological characteristics of a person, as well as social and environmental factors that allow one way or another to realize his potential" [10].

For example, J. Porokhin, L. Bayrachna and others under psychological rehabilitation potentional understand the system of premorbidly formed individual and psychological characteristics of the individual 
(motivational, emotional-volitional, cognitive), acting as the main resource in the case of the social situation changes as a result of the illness that disables the person and contribute to his re-adaptation.

Thus, it is indisputable that the state of rehabilitation potential is determined by those or other parameters at the biological, psychological and socio-environmental level. Fundamentally important in its definition is the discovery of stored resources at the biological and mental level, which can act as compensatory functions and help a person to adapt to new living conditions.

An interesting question is the establishment of connection between age aspect and adaptive, personal, motivational, interpersonal and pathopsychological components of psychological rehabilitation potential of patients with depressive disorders.

Material and methods. The sample of the study was 91 subjects with neurotic depressive disorders and 84 testees from general population (healthy).

Methods of research: For solving tasks in the work, the set of research methods was used: informational theoretical, verbal-communicative, psychometric, psychodiagnostic and methods of mathematical statistics.

Results and Discussion In the study of determination age components of psychological rehabilitation potential (PRP) of patients with depressive disorders, a correlation analysis of adaptive, personal, motivational, interpersonal and pathopsychological components of PRP of different age groups with depressive disorders was conducted. All subjects were divided due to their age into three groups: the first group included testees of 18-29 years, the second group - 30-39 years, and the third group - 40-49 years. Patients older than 50 years were not included in the comparison because the number of persons did not allow them to be statistically compared with other groups.

As a result of the study, the age-specific features of PRP with depressive disorders were determined. It has been established that social functioning, psychological well-being, viability, personal adaptation potential, coping strategies, peculiarities of interpersonal and family communication, individual-typological peculiarities and specifics of value-motivational sphere are important components that determine the PRP of patients with depressive disorders and have age specifics

Differentiated components of PRP, which are internal and external (environment) resources, were established and have the following form: in neurotic depressive disorders, PRP had the following parameters:

a) PRP at 20-29 years included: involvement and interest to life; communicative potential, self-confidence; updating of adaptive and relatively adaptive coping strat- egies: "protest", "emotional disorientation", "distraction" and "treatment"; typological features: domination, sociability; searching for impressions, dreaminess, artistry; ergopathic and egocentric types of attitude to the disease; importance of values "achievement", "kindness", "stimulation"; "hedonism", "freedom", openness to experience and others; orientation on the family system of achievement, control of each other's family members; cohesiveness and expressiveness in the manifestation of feelings in the family.

b) PRP at 30-39 years was: self-confidence; updating of adaptive and relatively adaptive coping strategies: "emotional endurance", "emotional disorientation", "relativity" and "protest"; the importance of values "kindness", "security" and "conformity"; family structuring, caring, ability to show negative emotions.

c) PRP at 40-49 years included: actualization of relatively adaptive coping strategies: "passive co-operation" and "compensation"; the importance of preserving traditions and customs that fit social norms.

Trigger mechanisms for the violation of the process of adaptation and compensation patients with depressive disorders are defined, they belong to: in neurotic depression: decrease in viability: decreased involvement in life $(\mathrm{DK}=2.55)$, average control $(\mathrm{DK}=1.09)$, low level of risk taking ( $\mathrm{DK}=8,24)$; reduction of adaptability of coping strategies $(\mathrm{DK}=3,10)$ : actualization of confusion $(\mathrm{DK}=10,38)$, suppression of emotions $(\mathrm{DC}=6,85)$, avoidance ( $\mathrm{DK}=7,40)$, passive co-operation $(\mathrm{DK}=9,07$ ), compensation ( $\mathrm{DK}=8,10)$, emotional discharge $(\mathrm{DK}=$ $3,54)$ and treatment $(\mathrm{DK}=7,82)$; reduction of adaptive potential: reduction of neuropsychic stability $(\mathrm{t}=2.756)$ and occurrence of asthenic $(\mathrm{t}=2.228)$, psychotic $(\mathrm{t}=$ 2.316) reactions and maladaptation disorders $(t=3.012)$.

Conclusions. Consequently, age-specific characteristics of PRP of patients with depressive disorders and their components were established. It has been proved that with age the level of psychological rehabilitation potential decreases gradually and the level of psychological rehabilitation deficit increases in all spheres of life of patients with depressive disorders, that manifested itself in the decrease of social functioning, psychological well-being, level of vitality, adaptive potential of personality, change of value-motivational sphere, violations of interpersonal and intra-family communication.

Thus, the findings should be taken into account in the determination of PRP for patients with depressive disorders and can be considered as age-differentiated targets for rehabilitation interventions in the development of differentiated psycho-correction programmes.

\section{REFRENCES}

1. Arshava, I. F. \& Nosenko, E. L. (2008), Aspects of implicit diagnostics of emotional stability of a person [Aspekty implitsytnoyi diahnostyky emotsiynoyi stiykosti lyudyny], DNU.

2. Arshava, I. F. \& Arshava, A. V. (2000), "Psychotherapeutic aspect of rehabilitation of some categories of flight dispatching staff as a method of improving psychological reliability" ["Psikhoterepevticheskiy aspekt reabilitatsii nekotorykh kategoriy letno-dispetcherskogo sostava kak metod povysheniya psikhologicheskoy nadezhnosti"], Conference materials «Man in aviation and the problem of maintaining his health»

- Materialy konferentsii «Chelovek v aviatsii i problema podderzhaniya yego zdorov'ya», p. 11-12.

3. Arshava, I. F., Nosenko E. L. \& Znanetska, O. M. (2011), Positive image of the "I" and psychological well-being [Pozytyvnist' obrazu «Ya» ta psykholohichne blahopoluchchya], "Innovation", Dnipropetrovsk.

4. Ball, A. (1989), "The concept of adaptation and its significance for psychology" ["Ponyatiye adaptatsii i yego znacheniye dlya psikhologii"], Psychology issues - Voprosy psikhologii, Vol. 1, p. 92-100.

5. Berezin, F. B., Miroshnikov, M. P., Sokolova, E. D. (2011), 
Methods of multilateral personality research (structure, bases of interpretation, some applications) [Metodika mnogostoronnego issledovaniya lichnosti (struktura, osnovy interpretatsii, nekotoryye oblasti primeneniya)], "Consultant PlusNew Technologies", Moscow.

6. Bezpalko, O. V., Zvereva, I. D. \& Laktionova, G. M. (2004), Social work in Ukraine [Sotsialna robota v Ukrayini], Center for Educational Literature, Kiev.

7. Burlakova, I. A., Apanasenko, L. G. \& Kondes, T. V. (1998), "Health of the nation and labor potential of Ukraine" ["Zdorov'ya natsiyi ta trudovyy potentsial Ukrayiny"], Scientific notes of the Institute of Economics, Management and Economic Law - Uchenyye zapiski Instituta ekonomiki, upravleniya i ekonomicheskogo prava, Vol. 2, p.119-121.

8. Chaika, V. (2012), "Innovatsiyna model rozvitku yak vidpovid on wikliki suchasnosti." ["Innovatsiyna model' rozvytku yak vidpovid' na vyklyky suchasnosti"], The notes of Ternopil National Pedagogical University and Volodymyr Gnatyuk’s Names. Seriya: Pedagogy - Notatky Ternopiskoho natsionalnoho pedahohichnoho universytetu ta imena Volodymyra Hnatyuka. Seriya: Pedahohika, p. 142-155.

9. Kapska, A. Y. (2004), Social Work: Technological Aspect [Sotsialna robota: tekhnolohichnyy aspekt], State center of social services for youth. Institute of social sciences work and management of N.P. Drahomanov, Kiev.

10. Khalak, M. E. (2009), "The role of the level of psychological rehabilitation potential of a disabled person in the process of psychological support" ["Rol' urovnya psikhologicheskogo reabilitatsionnogo potentsiala invalida $\mathrm{v}$ protsesse psikhologicheskogo soprovozhdeniya"], Actual issues of restorative medicine and the rehabilitation of patients with movement disorders - Aktual'nyye voprosy vosstanovitel'noy meditsiny i reabilitatsii bol'nykh s dvigatel'nymi rasstroystvami, p. 182183.

11. Kondryukova, V. V. (2011), “Adaptation to professional activity: socio-psychological aspect" ["Adaptatsiya do profesiynoyi diyal'nosti: sotsial'no-psykholohichnyy aspekt"], Legal bulletin of the University "KROK" Yurydychnyy byuleten universytetu "KROK", Vol. 9, p. 139143.

12. Lomov, B. F. (1975), "On the system approach in psychology" [“O sistemnom podkhode v psikhologii”], Psychology issues - Voprosy psikhologii, Vol. 2.

13. Maksimenko, S. D. (2013), "Features of prognostication of internal lines of mental health of personality" ["Osoblyvosti prohnozuvannya vnutrishnikh liniy psykhichnoho zdorovya osobystosti"], Problems of modern psychology - Problemy suchasnoyi psykholohiyi, Vol. 2, p. 4-14.

14. Maksimenko, S. D., Koval, V. V., Maksymenko, K. S. \& Papucha, M. V. (2008), Medical psychology [Medychna psykholohiya], The New Book, Vinnitsa.

15. Maksymenko, S. D. \& Shevchenko, N. F. (2007), "Psychological help for serious somatic patients: a manual" ["Psykholohichna dopomoha tyazhkym somatychno khvorym: navchal'nyy posibnyk"], Institute of Psychology named after G.S. Kostyuk of the Academy of Pedagogical Sciences of Ukraine - Instytut psykholohiyi imeni H.S. Kostyuka Akademiyi pedahohichnykh nauk Ukrayiny, p. 115.

16. Nosenko, E. L. \& Arshava, I. F. (2006), "System approach to the study of human resistance in the light of the newest researches of emotional and mental states" ["Systemnyy pidkhid do vyvchennya stiykosti lyudyny u svitli novitnikh doslidzhen emotsiynykh i psykhichnykh stani"], Institute of Psychology named after G.S. Kostyuk of the Academy of Pedagogical Sciences of Ukraine - Instytut psykholohiyi imeni H.S. Kostyuka Akademiyi pedahohichnykh nauk Ukrayiny, Vol. 8, No. 5, p. 229-243.

17. Pogodaev, K. I. (1996), "To the biological basis of "stress" and "adaptation syndrome" ["K biologicheskim osnovam «stressa» i «adaptatsionnogo sindroma»"], Actual problems of stress - Aktualni problemy stresu, p. 211-229.

18. Rogacheva, T. V. (2015), "Stages and tasks of comprehensive rehabilitation of a patient of a rehabilitation center (to the formulation of the problem)" ["Etapy i zadachi kompleksnoy reabilitatsii patsiyenta reabilitatsionnogo tsentra (k postanovke problemy)"], Medical psychology: electron. scientific journals - Meditsinskaya psikhologiya: elektron. nauchnyye zhurnaly, No. 6 (35).

19. Shagrai, V. M. (2006), Technologies of social work [Tekhnolohiyi sotsial'noyi roboty], Center for Educational Literature, Kiev.

20. Starobina, E. M., Svistunova, E. G. \& Gordievskaya, E. O. (2008), Psychological Aspects of the Rehabilitation Potential of Disabled Persons [Psikhologicheskiye aspekty reabilitatsionnogo potentsiala invalidov], Expert, St. Petersburg.

21. Voloshin, P. V. \& Maruta, N. O. (2015), "A strategy for the well-being of the psychiatric health of the population of Ukraine: modern citizens and pereskodi". ["Strategiya blagopoluchiya psikhiatricheskogo zdorov'ya naseleniya Ukrainy: sovremennyye grazhdane i pereskodi"], Ukrainian psychologist neuropsychiatry - Ukrayinska psykholohichna psykhonevrolohiya, Vol. 23, Issue 1 (82), p. 5-11. 